\title{
Pengaruh Kadar Air Awal dan Surcharge Pressure pada Uji Karakteristik Pengembangan Tanah Ekspansif
}

\author{
"Willis Diana, Edi Hartono, Anita Widianti \\ Fakultas Teknik, Universitas Muhammadiyah Yogyakarta \\ *willis.diana@umy.ac.id
}

Received: 6 September 2017 Revised:7 Oktober 2017 Accepted: 18 Oktober 2017

\begin{abstract}
Expansive soils experience volumetric changes due to water content changes. These volumetric changes cause swell and shrink movement in soils, which in turn will inflict severe damage to structures built above them. A proper understanding of how the expansive soil behaves during the wetting/drying process is essential for assessing the mitigation action and design suitable foundation. The structures that build above expansive soil bed are susceptible to heave and to withstand swell pressure, thus the swell pressure must be considered in the design. This study focuses on swelling properties of two expansive clay from Ngawi, East Java and Wates, Yogyakarta. Laboratory test on disturbed samples is used to identified and to measured swelling properties. A series of swelling test was performed under constant soil dry density. The influence of initial water content and surcharge pressure on swelling properties of compacted samples were investigated. The swelling properties test used ASTM standard 4546-03 method B. It was found that the lower initial water content the higher the swell percent, but the swell pressure seems not to be affected by initial water content. At the same initial water content, swell percent decrease with the increase of surcharge pressure, but swell pressure remains unchanged.
\end{abstract}

Keywords: Expansive soil; moisture content; surcharge pressure; swell pressure; swell percent

\begin{abstract}
Abstrak
Tanah ekspansif akan mengalami perubahan volume jika terjadi perubahan kadar air. Perubahan volume akan menyebabkan tanah mengalami pengembangan dan penyusutan, yang selanjutnya dapat menyebabkan kerusakan pada struktur diatasnya. Pemahaman yang baik tentang perilaku tanah ekspansif selama proses kembang susut tanah penting untuk menentukan metode pencegahan, perbaikan sifat tanah ekspansif, dan metode perancangan struktur yang tepat. Penelitian ini terfokus pada pengaruh kadar air awal dan tekanan (surcharge pressure) yang diberikan pada spesimen uji swell-consolidation tanah ekspansif terhadap karakteristik deformasi dan tekanan pengembangan tanah. Sampel tanah diambil dari Ngawi, Jawa Timur dan Wates, D.I. Yogyakarta. Pengujian soil properties untuk identifikasi dan swelling propeties terhadap sampel remoulded dilakukan di laboratorium. Sejumlah pengujian swelling properties berdasarkan ASTM standard 4546-03 metode B dilakukan terhadap sampel dengan berat volume kering yang sama dan variasi dilakukan terhadap kadar air awal sampel dan tekanan (surcharge pressure). Hasil pengujian menunjukan bahwa semakin rendah kadar air awal sampel, persen pengembangan semakin besar, tetapi tekanan pengembangan terlihat tidak dipengaruhi oleh kadar air awal. Semakin besar tekanan yang diberikan terhadap sampel, persen pengembangan semakin berkurang. Tekanan pengembangan tidak pula dipengaruhi oleh besarnya tekanan yang diterapkan (surcharge pressure) pada spesimen uji untuk kedua jenis sampel tanah.
\end{abstract}

Kata-kata kunci: Tanah ekpansif; kadar air; surcharge pressure; persen pengembangan; tekanan pengembangan. 


\section{Pendahuluan}

Tanah ekspansif adalah tanah yang dapat mengalami perubahan volume jika terjadi perubahan kadar air. Tanah jenis ini biasanya berupa tanah lempung koloidal yang berasal dari mineral hydrophilic seperti montmorillonite, illite, vermicullite, dsb. Pada saat tanah ekspansif mengalami pengembangan, tanah akan mengangkat fondasi atau bangunan di atasnya, jika besarnya gerakan pengangkatan ini berbeda antara satu titik dengan titik lainnya maka dapat menyebabkan bangunan di atasnya mengalami tegangan berlebih, timbul retak-retak, dan kerusakan struktur. Sehingga pengetahuan mengenai perilaku tanah ekspansif sangat penting, terutama untuk struktur-struktur dengan bentang yang luas dan struktur ringan, dengan berat sendiri relatif kecil, dan tidak mampu melawan tekanan pengembangan tanah.

Beberapa metode telah berkembang untuk memperkirakan besarnya pengembangan dan tekanan pengembangan tanah ekspansif. Secara umum metode ini dibagi menjadi dua, yaitu metode perkiraan langsung (direct) dan tidak langsung (indirect), metode tidak langsung adalah berdasarkan pendekatan statistik empiris dan semiempiris yang menghubungkan persen pengembangan dan tekanan pengembangan dengan parameter seperti batas-batas Atterberg, kandungan lempung, aktifitas, susut linier, kadar air, suction tanah, dan kombinasi dari dua atau beberapa parameter tersebut (Al-Shamrani dan Dhowian, 2003 Metode langsung berupa pengukuran pengembangan berdasarkan pengukuran heave (displacement vertikal) satu dimensi menggunakan alat oedometer dan pengukuran tiga dimensi menggunakan model alat triaksial. Pengujian deformasi pengembangan langsung di laboratorium terhadap sampel tidak terganggu (undistrub) maupun sampel remouded merupakan cara yang terbaik untuk menentukan potensi pengembangan dari tanah ekspansif ini (Kezhen dan Luocheng, 2009).

Faktor internal yang mempengaruhi besarnya persen pengembangan dan tekanan pengembangan di laboratorium seperti jenis mineral, luas permukaan spesifik tanah, kapasitas pertukaran kation, dan karakteristik dari air pori. Faktor eksternal seperti parameter pemadatan (berat volume kering dan kadar air), jenis usaha pemadatan, sifat jenis cairan yang digunakan (Agus et al., 2013) dan tekanan (surcharge pressure) yang diterapkan saat pengujian (Kezhen dan Luocheng, 2009.
Beberapa peneliti menyatakan bahwa kepadatan kering tanah adalah faktor yang paling menentukan karakteristik pengembangan tanah, ketika kepadatan kering meningkat, baik persen pengembangan maupun tekanan pengembangan akan meningkat (Chen, 1975; Villar \& Lloret, 2008; Kezhen dan Luocheng, 2009; Daffala, 2012; Zhang et al., 2006; Rashid et al., 2013; Mehmood et al., 2011). Kenzhen dan Loucheng (2009) menyatakan bahwa deformasi pengembangan adalah berbanding lurus dengan kadar air dan kepadatan kering, dan berbanding terbalik secara ekponensial dengan tekanan surcharge. Villar and Lloret (2008) menyatakan bahwa peningkatan kepadatan kering akan meningkatkan persen pengembangan dan tekanan pengembangan secara eksponensial. Tekanan pengembangan tidak dipengaruhi oleh kadar air awal, dan tekanan surcharge mempengaruhi persen pengembangan selama penjenuhan. Sorochan (1991) menyatakan bahwa tekanan pengembangan dipengaruhi oleh kepadatan kering dan kadar air. Chen (1975) menyimpulkan bahwa kepadatan kering adalah satu satunya faktor yang mempengaruhi tekanan pengembangan, tekanan pengembangan meningkat dengan peningkatan kepadatan kering. Tekanan pengembangan tidak dipengaruhi oleh tekanan surcharge, kadar air awal, derajat kejenuhan, dan ketebalan lapis tanah ekspansif.

Para peneliti telah menjelaskan pengaruh kadar air awal terhadap perilaku tanah ekpansif, sebagian meyebutkan bahwa persen pengembangan besarnya tergantung pada kadar air awal sampel, semakin besar kadar air awal, semakin kecil persen pengembangan, tetapi tekanan pengembangan tidak dipengaruhi oleh kadar air awal. Sedangkan peneliti lainnya menyebutkan bahwa kadar air awal mempengaruhi tidak saja persen pengembangan tetapi juga tekanan pengembangan. Perbedaan ini biasanya disebabkan karena perbedaan material specimen, beda peralatan, beda kondisi pembebanan, dan sebagainya. Sehingga hal ini tidak dapat digunakan sebagai standard secara umum, dan hanya bisa digunakan untuk tanah tanah tertentu di wilayah-wilayah tertentu Al-Shamrani dan Dhowian, 2003

Daffala (2012) menyarankan agar perkiraan parameter pengembangan tanah ekspansif seharusnya tidak berdasarkan pada sifat tanah yang berbeda asal dan komposisi mineralnya. Perilaku dan kecenderungan tanah ekspasif dari literatur dan jurnal hanya bisa digunakan sebagai petunjuk umum dan pengaruh faktor-faktor seperti kadar air awal dan tekanan surcharge harus diuji pada masing-masing tanah, sebab kandungan lempung dan mineral masing-masing tanah sangat mempengaruhi keseluruhan perilaku perubahan 
volume, dan harus dilakukan penilaian secara kasus perkasus.

Penelitian ini menitikberatkan pada pengukuran parameter pengembangan tanah, yaitu persen pengembangan dan tekanan pengembangan tanah pada dua jenis tanah ekspansif dari Ngawi, Jawa Timur dan Wates, D.I. Yogyakarta terhadap pengaruh kadar air awal dan tekanan surcharge, karena kondisi awal (placement condition) memegang peranan penting terhadap perilaku proses pengembangan (swelling) tanah ekspansif. Disamping hal tersebut, pemahaman yang menyeluruh dan benar terhadap proses kembang susut tanah ekspansif sangat penting untuk menentukan tindakan pencegahan, perbaikan, dan perancangan struktur yang berdiri di atas tanah ekspansif.

\section{Material Sampel dan Program Penelitian}

Untuk menyamakan persepsi, beberapa istilah yang digunakan dalam tulisan ini memiliki pengertian sebagai berikut, pengembangan (heave) berarti penambahan tebal (tinggi) $(\Delta \mathrm{h})$, dari suatu kolom tanah dengan tinggi semula (h) yang menyertai penyerapan air. Persen pengembangan adalah rasio penambahan atau pengurangan tinggi $(\Delta \mathrm{h})$, terhadap tinggi awal kolom tanah atau $\Delta \mathrm{h} / \mathrm{h} \mathrm{x}$ 100. Tekanan pengembangan adalah tekanan yang dibutuhkan untuk mengembalikan spesimen tanah kembali pada ukuran asalnya (baik tinggi maupun angka pori awal) setelah spesimen mengalami pengembangan. Tekanan surcharge (surcharge pressure) adalah tekanan yang diterapkan pada spesimen saat pengujian swell-consolidation.

\section{Material properties}

Tanah ekspansif diperoleh dari desa Soko, Ngawi, Jawa Timur dan Wates, DI Yogyakarta, tanah lempung dari kedua daerah tersebut diketahui memiliki tingkat ekspansifitas sedang sampai tinggi (Binamarga, 2005). Sampel distrubed dikumpulkan dari lokasi pada kedalaman $1 \mathrm{~m}$ sampai dengan $2 \mathrm{~m}$ dari permukaan tanah. Tanah kemudian dikeringkan, dihaluskan dan disaring hingga lolos saringan no. 10. Sifat fisik tanah seperti pada Tabel 1 .

Dari sifat fisik tanah dalam Tabel 1, nilai batasbatas Atterberg menunjukan bahwa tanah yang digunakan sebagai sampel memiliki tingkat ekspansifitas yang tinggi. Berdasarkan nilai Free Swell Ratio (FSR) dan Free Swell Index (FSI) kedua tanah memiliki tingkat ekspansifitas yang kritis sampai parah.
Tabel 1. Sifat fisik tanah

\begin{tabular}{lrc}
\hline \multicolumn{1}{c}{ Soil properties } & $\begin{array}{c}\text { Sampel } \\
\text { tanah } \\
\text { Ngawi }\end{array}$ & $\begin{array}{c}\text { Sampel } \\
\text { tanah } \\
\text { Wates }\end{array}$ \\
\hline Specific gravity & 2,65 & 2,60 \\
Batas cair (\%) & 94,39 & 88,11 \\
Batas plastis (\%) & 34,58 & 26,05 \\
Batas susut (\%) & 11,63 & 12,73 \\
Indeks plastisitas (PI) (\%) & 59,81 & 57,26 \\
Percent finner $<$ 2 $\mu \mathrm{m}(\%)$ & 96,32 & 87,32 \\
Klasifikasi USCS & $\mathrm{CH}$ & $\mathrm{CH}$ \\
Kepadatan kering & 1,25 & 1,31 \\
maksimum & & \\
(Proctor Standard) (gr/cm $\left.{ }^{3}\right)$ & & \\
Kadar air optimum & 35,55 & 27,00 \\
(Proctor Standard) (\%) & & \\
Aktifitas (Chen, 1975) & 3,82 & 2,50 \\
FSR (Sridharan \& Prakash, & 2,00 & 1,50 \\
2000) & & \\
FSI (Sridharan \& Prakash, & 100,00 & 45,50 \\
2000) (\%) & & \\
\hline
\end{tabular}

\section{Persiapan spesimen}

Baik sampel tanah dari Ngawi maupun Wates, sebelum pengujian swell consolidation, terlebih dahulu dilakukan uji pemadatan dengan standar Proctor. Hasil uji pemadatan dengan standard Proctor diperoleh berat volume kering maksimum untuk tanah lempung ekspansif Ngawi sebesar $1,25 \mathrm{~g} / \mathrm{cm}^{3}$ dengan kadar air optimum sebesar $35,55 \%$. Untuk lempung ekspansif Wates, berat volume kering maksimum diperoleh sebesar 1,31 $\mathrm{g} / \mathrm{cm}^{3}$ dan kadar air optimum $27,00 \%$. Hasil dari uji Proctor ini yang dijadikan acuan untuk menentukan berat volume kering spesimen untuk uji swell consolidation.

Semua spesimen remoulded untuk sampel tanah dari Ngawi dipadatkan dengan berat volume kering konstan sebesar $1,25 \mathrm{~g} / \mathrm{cm}^{3}$ dengan kadar air awal bervariasi sebesar $10 \%$, $20 \%$ dan $35,55 \%$. Untuk sampel tanah Wates, spesimen dipadatkan dengan berat volume kering konstan sebesar $1,31 \mathrm{~g} / \mathrm{cm}^{3}$ dan kadar air awal sebesar 9\%, 27\%, dan 34\%, kadar air divariasikan sesuai dengan variasi kadar air alami yang mungkin dialami tanah saat kering.

Agar dihasilkan kadar air awal sesuai dengan yang direncanakan, tanah kering dicampur dengan air dengan proporsi tertentu sehingga diperoleh kadar air seperti yang direncanakan. Campuran tanah dan air ini dibiarkan beberapa hari dalam kantong plastik pada kondisi suhu ruangan, sehingga diperoleh kadar air yang seragam untuk satu variasi kadar air. Tekanan surcharge untuk kedua jenis sampel divariasikan sebesar $1,2 \mathrm{kPa}, 6,9 \mathrm{kPa}$, $10 \mathrm{kPa}, 20 \mathrm{kPa}$. Variasi pengujian ditampilkan dalam Tabel 2. 
Tabel 2. Variasi pengujian

\begin{tabular}{lcc}
\hline \multicolumn{1}{c}{ Sampel } & $\begin{array}{c}\text { Kadar air } \\
\text { wal }(\%)\end{array}$ & $\begin{array}{c}\text { Tekanan } \\
\text { surcharge }(\mathbf{k P a})\end{array}$ \\
\hline Sampel tanah & 10,00 & 1,20 \\
Ngawi & 10,00 & 6,90 \\
& 10,00 & 10,00 \\
& 10,00 & 20,00 \\
& 20,00 & 6,90 \\
& 35,50 & 6,90 \\
\hline Sampel tanah & 9,00 & 6,90 \\
wates & 27,00 & 6,90 \\
& 27,00 & 10,00 \\
& 27,00 & 20,00 \\
& 35,00 & 6,90 \\
\hline
\end{tabular}

\section{Program Penelitian}

Untuk melakukan penelitian ini, digunakan frame oedometer dan sel oedometer konvensional. Spesimen dipadatkan langsung dalam cincin oedometer yang berdiameter $6,35 \mathrm{~cm}$ dan tinggi $2,00 \mathrm{~cm}$. Tinggi awal spesimen kurang lebih 1,60 $\mathrm{cm}$. Spesimen yang telah dipadatkan, diletakkan dalam sel oedometer dengan batu pori dibagian atas dan bawahnya.

Tekanan surcharge diberikan pada spesimen sebelum sel oedometer digenangi air. Besarnya tekanan surcharge seperti pada Tabel 2. Pengujian dilakukan sesuai standar ASTM D4546 metode B. Spesimen dijenuhkan dengan cara sel oedometer digenangi air, sehingga spesimen mengembang. Regangan pengembangan (persen pengembangan) yang dialami spesimen selama penjenuhan dicatat sebagai fungsi dari waktu. Pengujian pengembangan (swell) dilakukan sampai terjadi pengembangan sekunder, dimana laju penambahan pengembangan berikutnya sudah tidak signifikan (kurva persen pengembangan terhadap logaritma waktu sudah asimtotis). Setelah terjadi pengembangan sekunder, dilanjutkan dengan uji konsolidasi. Spesimen diberikan beban dua kali dari beban sebelumnya, penurunan yang terjadi dicatat, uji konsolidasi untuk satu tingkat tekanan surcharge dilakukan selama 24 jam. Pengujian konsolidasi dilakukan sampai sampel kembali ke tinggi awal. Tekanan yang membuat sampel mencapai tinggi awal (angka pori awal) disebut tekanan pengembangan.

\section{Hasil dan Pembahasan}

Hasil yang diperoleh dari penelitian ini disajikan dalam Tabel 3.

\section{Persen pengembangan}

Kurva persen pengembangan terhadap logaritma waktu seperti pada Gambar 1. Pengaruh kadar air awal terhadap persen pengembangan seperti pada Gambar 2. Hasil penelitian menunjukan bahwa persen pengembangan pada tingkat tegangan surcharge tertentu menunjukan penurunan dengan membesarnya kadar air awal. Kadar air awal spesimen mengontrol besarnya pengembangan tanah, tanah lempung yang relatif lebih kering lebih mudah menyerap air. Pengurangan kadar air akan meningkatkan daya afinitas (tarikan) air untuk meningkatkan matric suction dan meyebabkan mengembangnya tanah (Chen, 1975). Ketika kadar air meningkat, kemampuan tanah untuk meyerap air menjadi berkurang dan menyebabkan terjebaknya udara dalam rongga pori sehingga sulit menggantikan rongga pori yang telah terisi udara dengan air serta sulit mencapai kontinuitas fase air dan udara.

Tabel 3. Hasil uji swell-consolidation tanah ekspansif

\begin{tabular}{ccccc}
\hline Sampel & $\begin{array}{c}\text { Kadar air awal } \\
(\boldsymbol{\%})\end{array}$ & $\begin{array}{c}\text { Tekanan } \\
\text { surcharge } \mathbf{( k P a )}\end{array}$ & $\begin{array}{c}\text { Persen } \\
\text { pengembangan } \\
(\boldsymbol{\%})\end{array}$ & $\begin{array}{c}\text { Tekanan } \\
\text { pengembangan } \\
(\mathbf{k P a})\end{array}$ \\
\hline Sampel tanah Ngawi & 10,00 & 1,20 & 27,73 & 140 \\
& 10,00 & 6,90 & 13,56 & 140 \\
& 10,00 & 10,00 & 12,10 & 145 \\
& 10,00 & 20,00 & 6,45 & 130 \\
& 20,00 & 6,90 & 10,26 & 110 \\
Sampel tanah Wates & 35,50 & 6,90 & 8,27 & 145 \\
& 9,00 & 6,90 & 18,91 & 135 \\
& 27,00 & 6,90 & 11,03 & 140 \\
& 27,00 & 10,00 & 9,92 & 140 \\
& 27,00 & 20,00 & 3,51 & 150 \\
& 35,00 & 6,90 & 4,07 & 100 \\
\hline
\end{tabular}




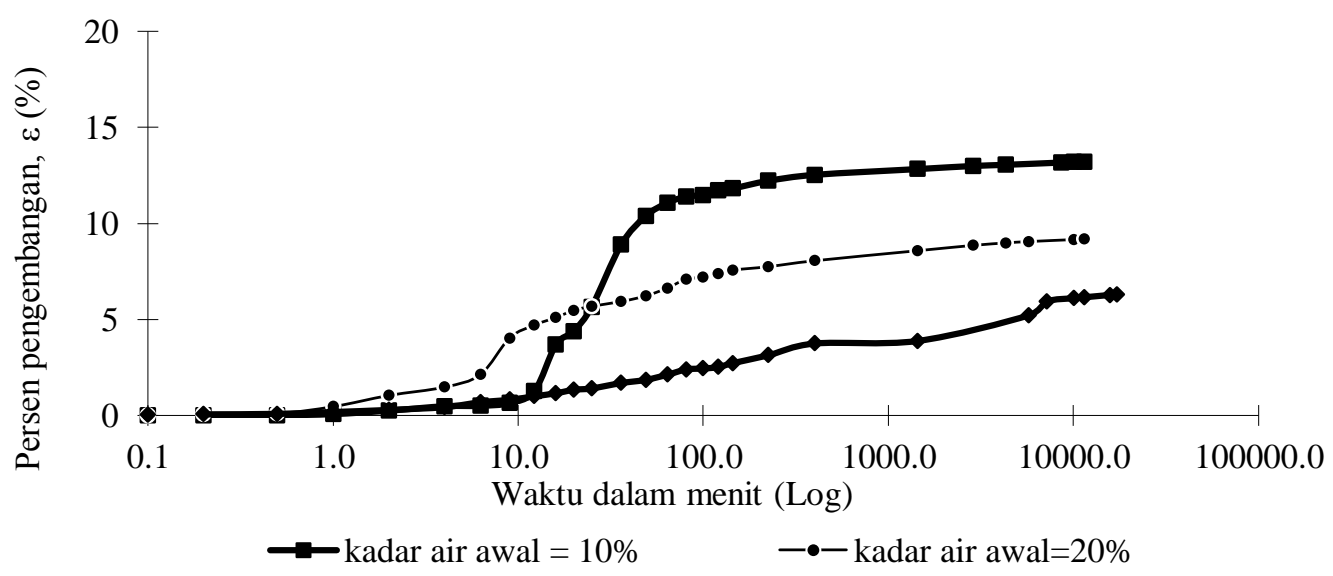

(a). Sampel tanah Ngawi

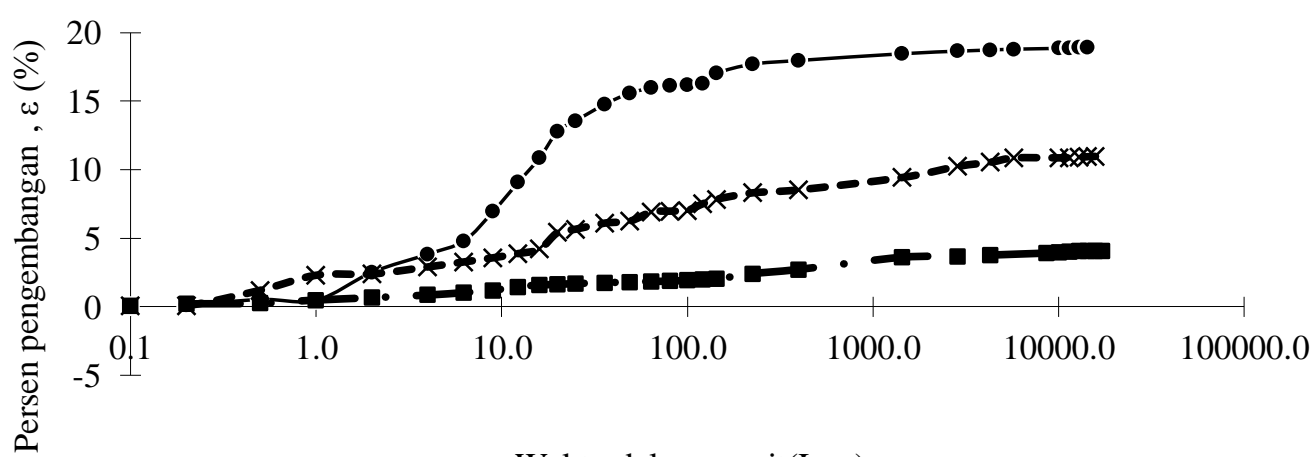

Waktu dalam menit( $\log )$

—— kadar air awal $=9,10 \%$

$-\not-$ kadar air awal $=27 \%$

(b). Sampel Tanah Wates

Gambar 1. Persen pengembangan terhadap logaritma waktu.

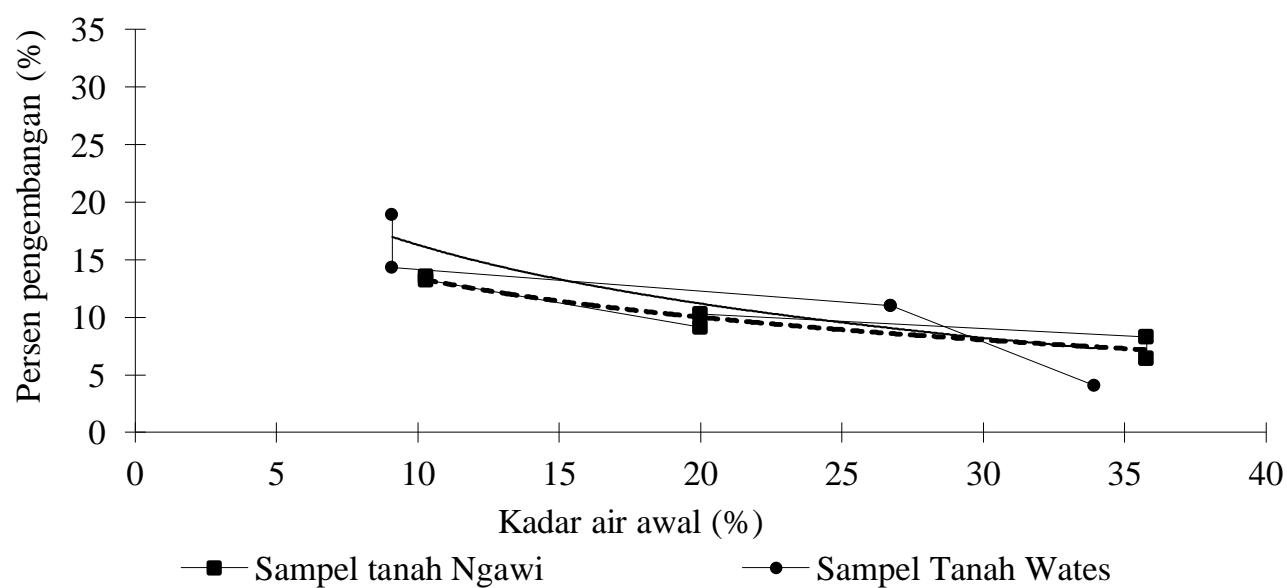

Gambar 2. Pengaruh kadar air awal terhadap persen pengembangan.

Gambar 2 memperlihatkan kecenderungan penurunan persen pengembangan pada kadar air awal yang semakin tinggi dan konvergen pada persen pengembanga sekitar $6 \%$ pada kadar air yang sangat tinggi. Kadar air awal pada saat pencampuran sampel remoulded mempengaruhi perilaku ekspansivitas tanah, sehingga banyak perhitungan perkiraan pengembangan tanah ekspansif menggunakan kadar air awal sebagai parameter dasarnya (Dafalla, 2012).

Gambar 3 dan 4 menunjukan besarnya persen pengembangan terhadap fungsi waktu untuk berbagai variasi tekanan surcharge. 


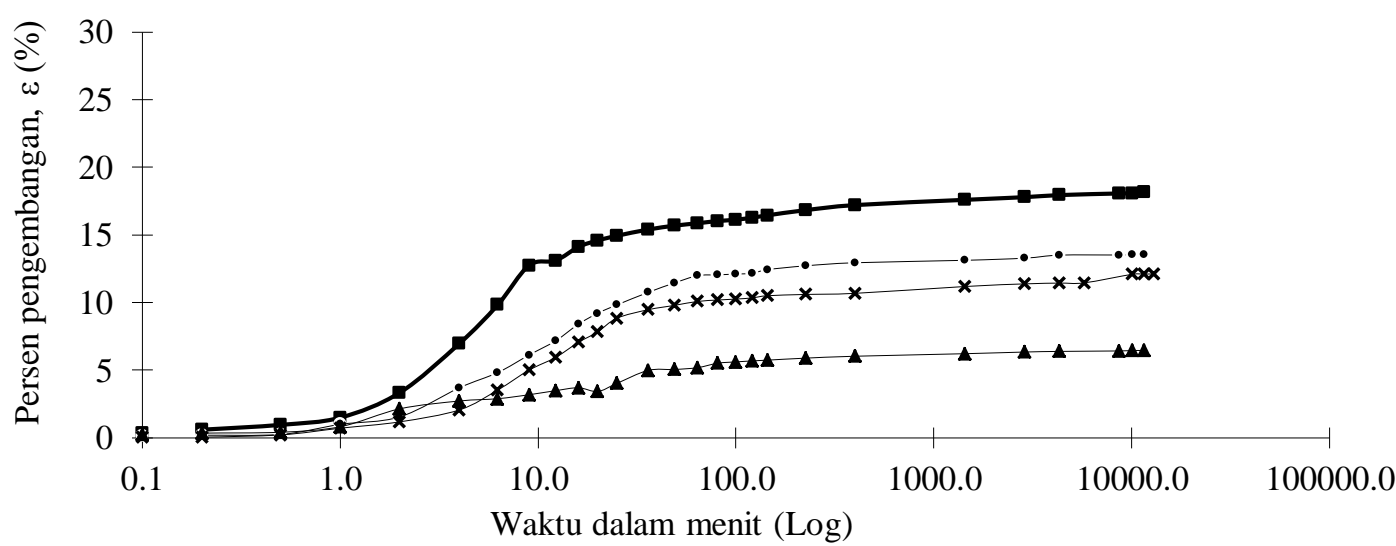
$\rightarrow$ Tekanan surcharge $1.2 \mathrm{kPa}$
-.-Tekanan surcharge $6.9 \mathrm{kPa}$
× Tekanan surcharge $10 \mathrm{kPa}$
— Tekanan surcharge $20 \mathrm{kPa}$

(a). Sampel tanah Ngawi

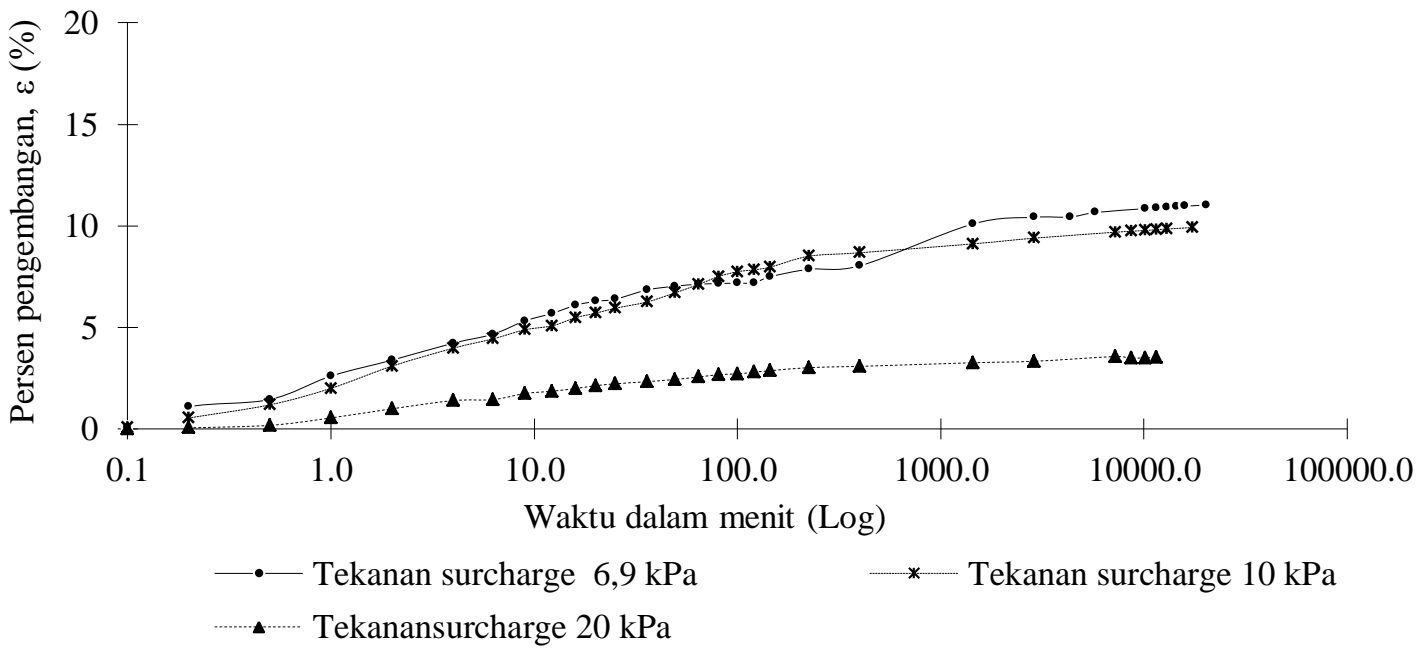

(b). Sampel tanah Wates

Gambar 3. Persen pengembangan terhadap logaritma waktu pada berbagai tingkat tekanan surcharge.

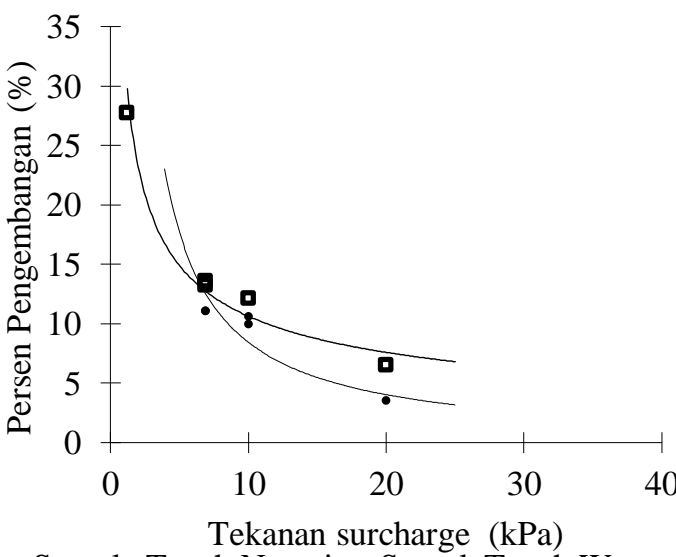

- Sample Tanah Ngawi • SampleTanah Wates

Gambar 4. Hubungan persen pengembangan terhadap pengaruh tekanan surcharge.
Gambar 3 dan 4 tersebut menunjukan bahwa persen pengembangan semakin besar pada beban (tekanan surcharge) yang semakin kecil. Semakin membesar tekanan surcharge, persen pengembangan semakin berkurang. Hal ini disebabkan saat tanah mengembang, akan timbul gaya angkat, yang dilawan (diseimbangkan) dengan tekanan surcharge, jika tekanan surcharge relatif besar, pengembangan akan tertahan sehingga persen pengembangan berkurang.

\section{Tekanan pengembangan (swelling pressure)}

Pengaruh kadar air awal spesimen terhadap tekanan pengembangan seperti dalam Gambar 5 dan 6 . 


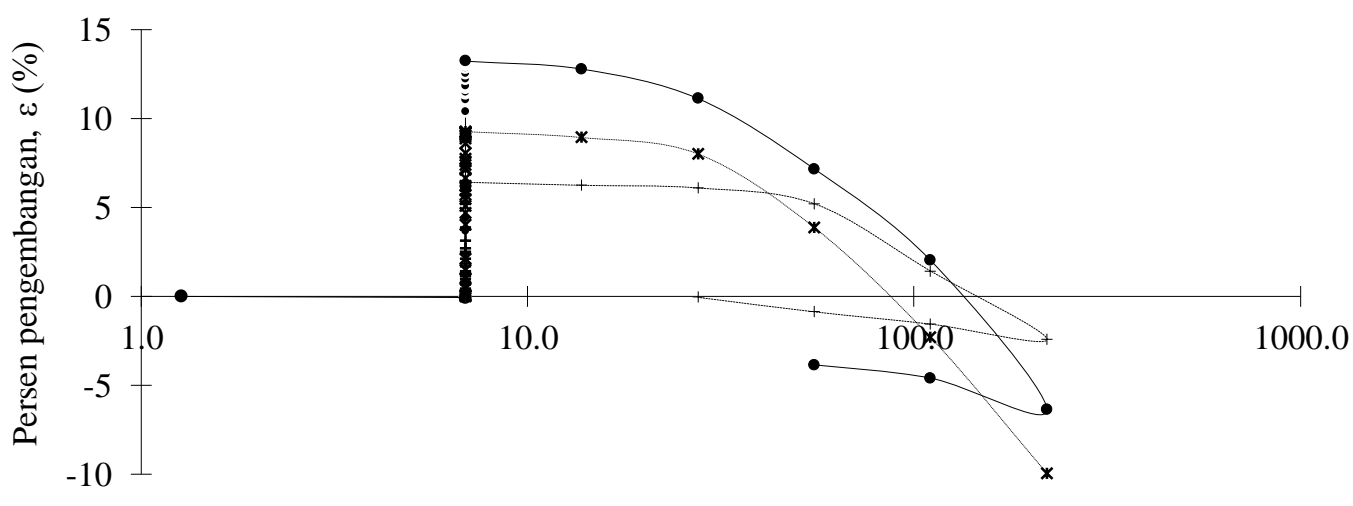

Tekanan, $\sigma \mathrm{v} \mathrm{kPa}(\log )$

- - kadar air awal, $\mathrm{w}=10 \%$

— kadar air awal, $\mathrm{w}=35,79 \%$

$\times$ kadar air awal, $w=20 \%$

* Series5

(a). Sampel tanah Ngawi

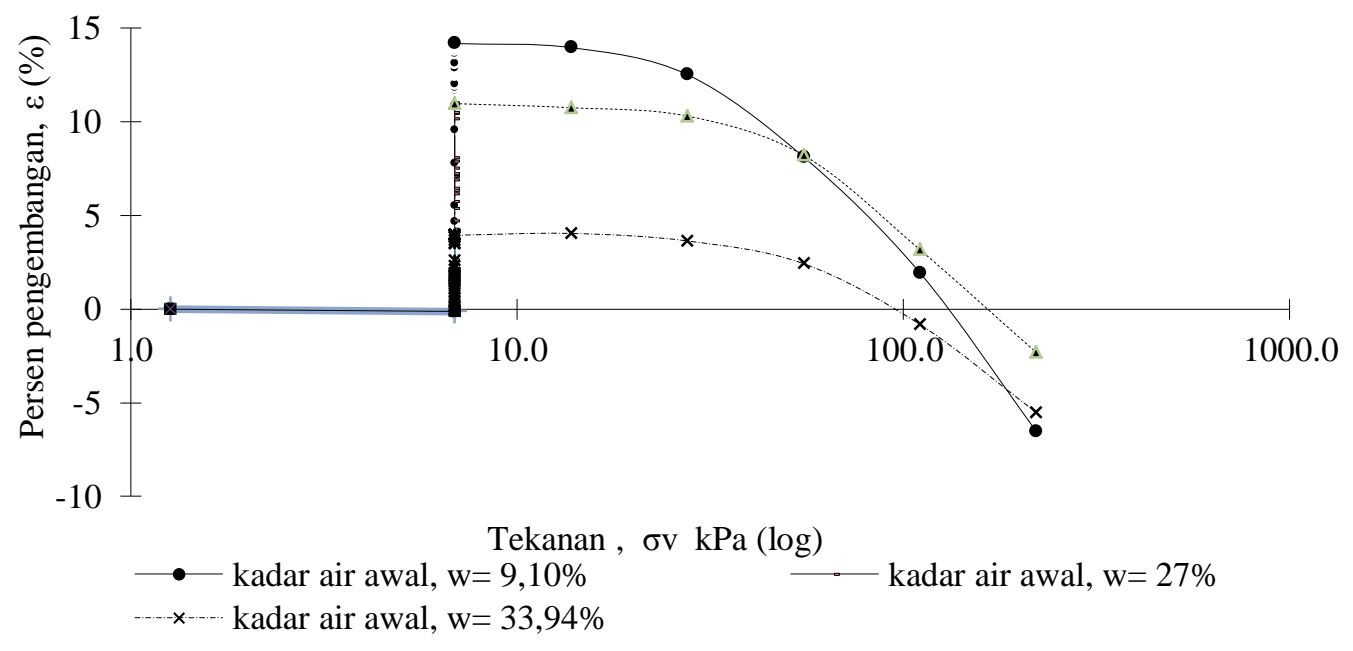

(b) Sampel tanah Wates

Gambar 5. Hubungan persen pengembangan dengan tekanan pada berbagai tingkat kadar air awal.

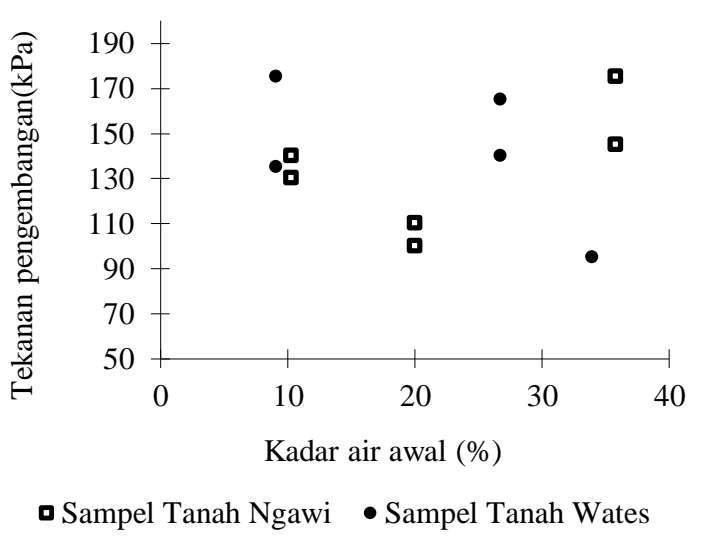

Gambar 6. Hubungan tekanan pengembangan dengan kadar air awal spesimen
Gambar 7 dan 8 menunjukan pengaruh tekanan surcharge terhadap tekanan pengembangan tanah.

Hasil yang disajikan pada Gambar 5 sampai dengan 8 menunjukan bahwa tekanan pengembangan tidak dipengaruhi oleh kadar air awal spesimen dan tekanan surcharge, hasil serupa juga disampaikan oleh Chen (1975) dan Villar dan Lloret (2008). Jika tekanan surcharge yang dibebankan pada spesimen selama penjenuhan lebih rendah dari tekanan prakonsolidasi, akan menyebabkan perubahan volume yang besar pada mikrostruktur dan berkontribusi besar pada perubahan volume makrostruktur. Jika tekanan surcharge yang diaplikasikan lebih besar atau sama dengan tekanan prakonsolidasi, regangan mikrostruktur dan makrostuktur cenderung berkurang, sehingga pengaruh kadar air awal akan berkurang. 


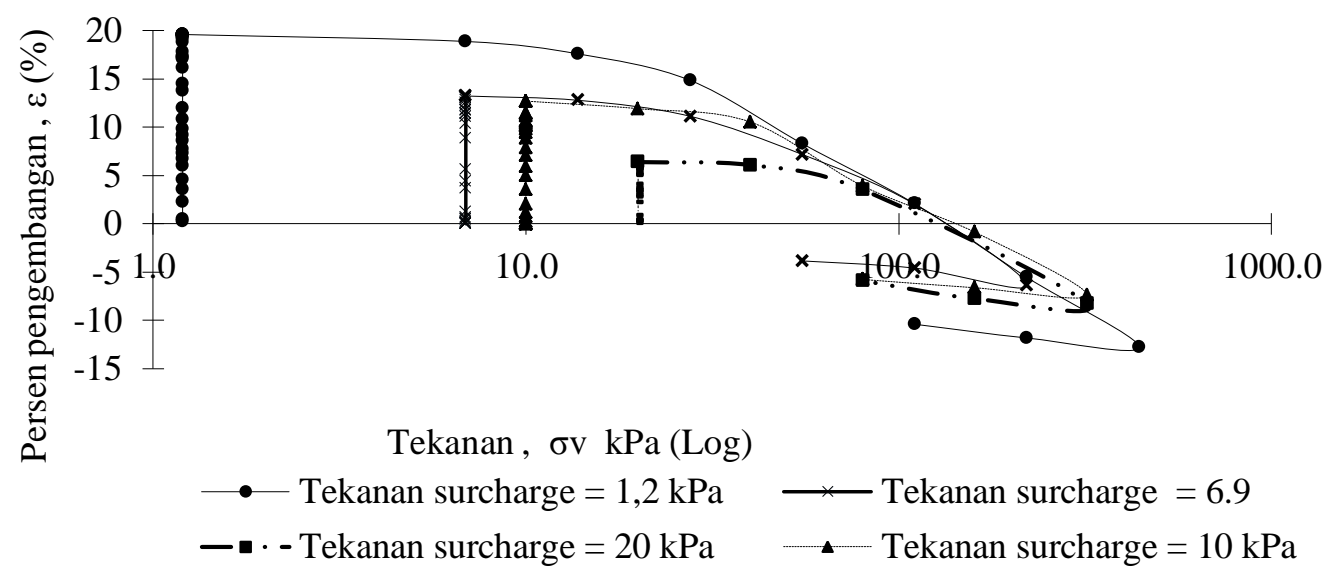

(a) Sampel tanah Ngawi

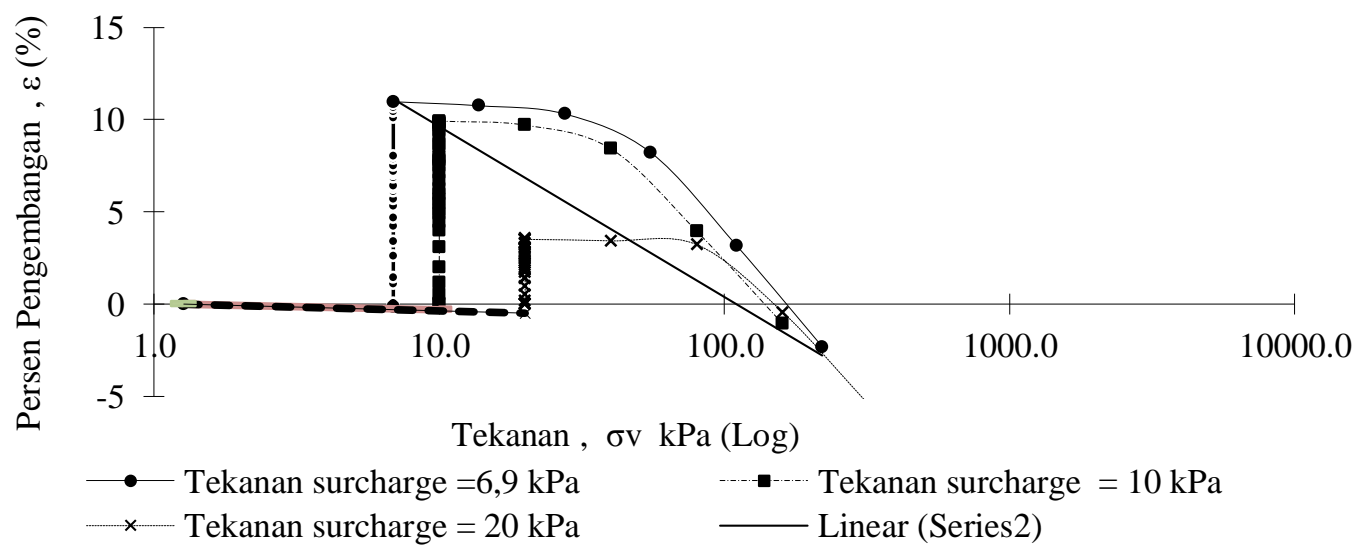

(b) Sampel tanah Wates

\section{Gambar 7. Hubungan persen pengembangan dengan tekanan pada berbagai variasi tekanan} surcharge.

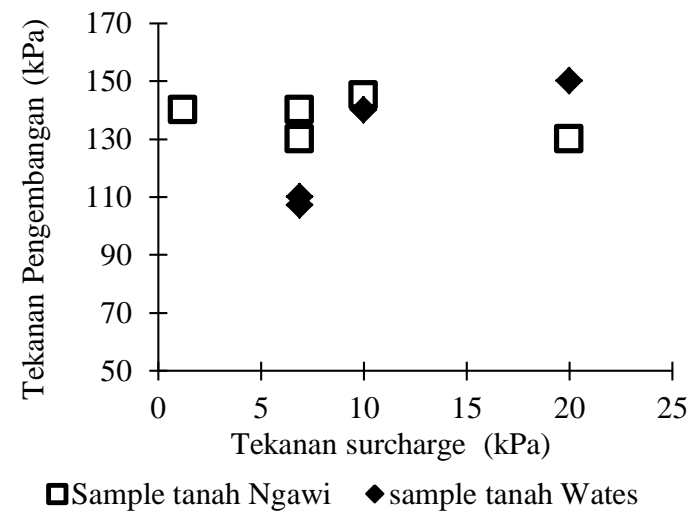

Gambar 8. Hubungan tekanan pengembangan dengan tekanan surcharge.

Temuan bahwa tekanan pengembangan tidak dipengaruhi oleh kadar air awal sangat membantu untuk penilaian kelayakan proses perbaikaan tanah ekspansif seperti prewetting dan pengontrolan pembasahan (controlled wetting). Metode peningkatan kadar air (pembasahan) pada tanah ekspansif sebelum memulai konstruksi bukan metode yang efektif untuk mengontrol pengembangan tanah, walaupun persen pengembangan berkurang, tetapi tekanan pengembangan tanah yang membebani fondasi atau struktur diatasnya tetap sama besarnya. Sehingga, walaupun telah dilakukan pra pembasahan (pre-wetting) sebelumnya, pada perancangannya tekanan pengembangan harus diperhitungan dalam perencanaan strukturnya.

\section{Kesimpulan}

Pengujian swell-consolidation telah dilakukan dan swelling properties untuk kedua jenis tanah telah diperoleh. Besarnya persen pengembangan dipengaruhi oleh nilai kadar air awal dan tekanan pengembangan. Makin besar nilai kadar air awal, semakin kecil persen pengembangan tanah, hal ini berlaku untuk kedua tanah ekspansif. 
Semakin besar tekanan surcharge yang diaplikasikan pada spesimen untuk kedua jenis tanah, semakin kecil persen pengembangan tanah. Artinya kondisi awal sampel (placement condition) sangat mempengaruhi perilaku pengembangan tanah ekspansif.

Persen pengembangan untuk tanah sampel dari Ngawi sebesar 27,73\% dan tekanan pengembangana sebesar $140 \mathrm{kPa}$ untuk spesimen dengan kadar air awal 10\% dan tekanan surcharge yang membenani spesimen sebesar 1,2 kPa.

Persen pengembangan untuk tanah sampel dari Wates sebesar $18,91 \%$ dan tekanan pengembangana sebesar $135 \mathrm{kPa}$ untuk spesimen dengan kadar air awal 9\% dan tekanan surcharge yang membenani spesimen sebesar $6,9 \mathrm{kPa}$.

Pada penelitian ini besarnya tekanan pengembangan tanah tidak dipengaruhi oleh nilai kadar air awal dan tekanan surcharge. Spesimen yang diuji dengan berbagai variasi kadar air awal menghasilkan tekanan pengembangan yang sama.

Pemberian tekanan surcharge yang lebih besar menurunkan persen pengembangan, tetapi tekanan pengembangan relatif tetap.

\section{Ucapan Terima Kasih}

Penelitian ini terlaksana melalui Hibah Penelitian Produk Terapan (PPT) Ristek Dikti Tahun 2017, sesuai Surat Perjanjian Pelaksanaan Nomor: 047/HB-LIT/IV/2017, Jum'at 14 April 2017; SP DIPA-042.06.1.401516/2017; tertanggal 7 Desember 2016. Diucapkan terima kasih kepada Kementrian Riset dan Teknologi Dikti Republik Indonesia, Kopertis Wilayah V dan LP3M UMY atas dana dan dukungan pada penelitian ini.

\section{Daftar Pustaka}

Agus, S. S., Arifin, Y. F., Tripathy, S., \& Schanz, T. (2013). Swelling pressure-suction relationship of heavily compacted bentonite-sand mixtures. Acta Geotechnica, 8(2), 155-165.
Al-Shamrani, M. A., \& Dhowian, A. W. (2003). Experimental study of lateral restraint effects on the potential heave of expansive soils. Engineering Geology, 69(1), 63-81.

Chen, F. H. (1975). Foundations On Expansive Soils (First ed.). Amsterdam, Netherlands: Elsevier.

Dafalla, M. A. (2012). The influence of placement conditions on the swelling of variable clays. Geotechnical and Geological Engineering, 30(6), 1311-1321.

Yan, K., \& Wu, L. (2009). Swelling Behavior of Compacted Expansive Soils. In Recent Advancement in Soil Behavior, in Situ Test Methods, Pile Foundations, and Tunneling: Selected Papers from the 2009 GeoHunan International Conference (pp. 1-6).

Mehmood, E., Ilyas, M., \& Farooq, K. (2011). Effect of initial placement conditions on swelling characteristics of expansive soils. In Geo-Frontiers 2011: Advances in Geotechnical Engineering (pp. 2397-2403).

Rashid, I., Farooq, K., Mujtaba, H., \& Khan, A. H. (2013). Treatment of Expansive Clays Throught Compaction Control. Pakistan Journal of Science, 65(1), 103-107.

Sorochan. (1991). Construction of Buildings on Expansive Soils. Brookfield: A.A. Balkema Publishers.

Villar, M. V., \& Lloret, A. (2008). Influence of dry density and water content on the swelling of a compacted bentonite. Applied Clay Science, 39(1), $38-49$.

Zhang, R., Yang, H., \& Zheng, J. (2006). The effect of vertical pressure on the deformation and strength of expansive soil during cyclic wetting and drying. In Unsaturated Soils 2006 (pp. 894905). 